\title{
Annual succession of marine pelagic protozoans in Disko Bay, West Greenland, with emphasis on winter dynamics
}

\author{
Henrik Levinsen ${ }^{1, *}$, Torkel Gissel Nielsen ${ }^{1}$, Benni Winding Hansen ${ }^{2}$ \\ ${ }^{1}$ National Environmental Research Institute, Department of Marine Ecology, Frederiksborgvej 399, \\ PO Box 358, 4000 Roskilde, Denmark \\ ${ }^{2}$ Roskilde University, Department of Life Sciences and Chemistry, PO Box 260, 4000 Roskilde, Denmark
}

\begin{abstract}
The succession of pelagic ciliates and heterotrophic dinoflagellates was investigated in Disko Bay, West Greenland, from April 1996 to June 1997. In terms of biomass they contributed equally. Their annual distribution was bimodal with maxima in May/June and August. Summer levels were similar to those reported at lower latitudes. Winter dynamics were different. Due to 2 mo of polar darkness, food concentrations for ciliates and heterotrophic dinoflagellates were below threshold concentrations for growth. Nonetheless, small populations persisted throughout the winter. Both

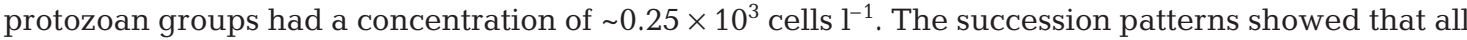
individual species peaked at different times during the summer months. However, diversity of the winter community was not different from that observed during summer. Even in the polar winter, the autotrophic ciliate Myrionecta rubra and the obligate mixotrophic ciliate Laboea strobila were recorded. Different strategies for winter survival of protozoans are discussed.
\end{abstract}

KEY WORDS: Protozoa $\cdot$ Ciliates · Heterotrophic dinoflagellates · Plankton structure and dynamics Winter survival strategies $\cdot$ Arctic microbial food web $\cdot$ Metabolism

Resale or republication not permitted without written consent of the publisher

\section{INTRODUCTION}

It has become evident that southern and northern polar waters share the same basic food web structure (Andersen 1988, Garrison \& Buck 1989, Sherr et al. 1997, Edwards et al. 1998). It has also been demonstrated that Arctic and Antarctic marine pelagic food webs show the same complexity as lower latitude ecosystems (von Bröckel 1981, Garrison \& Gowing 1993, Nielsen \& Hansen 1995, Rivkin et al. 1996). Research now suggests that protozoa are pivotal members of polar marine food webs (von Bröckel 1981, Hewes et al. 1985, Paranjape 1987, 1988, Andersen 1988, Smetacek et al. 1990). The dominant protozoans

*E-mail: sandal-levinsen@get2net.dk include mixo- and heterotrophic ciliates and dinoflagellates (e.g. Levinsen et al. 1999). These groups of organisms are able to consume a wide size range of prey; from bacteria to large diatoms.

To quantify the trophic role of protozoans, much effort has been put into growth measurements (e.g. Stoecker et al. 1983). By comparison, few studies have focused on their response to starvation in natural environments. From the perspective of a protozoon, survival during periods of resource limitation is of fundamental importance. At present, most knowledge comes from laboratory experiments (reviewed by Fenchel \& Finlay 1983, Caron et al. 1990). These studies describe how some protozoa drastically reduce their metabolism in response to starvation. The polar winter is the most unfavorable environment for marine primary producers and hence for heterotrophic organisms that depend on 
this food source. However, winter field studies in cold oceans have rarely been conducted (Garrison et al. 1993, Scharek et al. 1994, Rysgaard et al. 1999). Protozoan winter dynamics are poorly understood, although 'winter' is the prevailing season at high latitudes.

This study describes the annual succession of ciliates and heterotrophic dinoflagellates and their community structure in Disko Bay on the western coast of Greenland. Sampling throughout the winter enables us to discuss how heterotrophic protists overwinter when phytoplankton production is zero/negligible. To our knowledge, this paper is the first on the annual cycle of ciliates and heterotrotrophic dinoflagellates in a polar marine ecosystem.

\section{METHODS}

Study site and program. From April 1996 to June 1997 a 250 m deep station in Disko Bay, West Greenland $\left(\sim 69^{\circ} \mathrm{N}\right)$ was sampled 52 times (Fig. 1). During the ice-free period sampling was carried out from RV 'Porsild' (Arctic Station in Qeqertarsuaq, University of
Copenhagen). When the Bay was ice-covered, dogsledges were used for transport and sampling was done through a hole in the sea ice.

Hydrography and other physical measurements. Vertical profiles of salinity, temperature, and chlorophyll fluorescence were obtained from the surface to just above the bottom with a Seabird CTD system. Water density was calculated from salinity and temperature according to Fofonoff \& Millard (1983). Arctic Station, University of Copenhagen, provided data on solar irradiance and ice cover.

Water sampling. Water was collected from 5 to 6 depths in the upper 30 to $60 \mathrm{~m}$ of the water column with a Niskin bottle. During part of the winter when the upper water column was mixed, water collection was restricted to 2 and $15 \mathrm{~m}$. More intensive sampling was carried out monthly when an additional 4 depths $(50,100,150,200 \mathrm{~m})$ were included to improve the vertical resolution.

Ice communities. In spring, water from the ice-water interface and ice cores (triplicates) were collected and processed according to Garrison \& Buck (1986) and Grastrup-Hansen (1998) in order to determine the con-
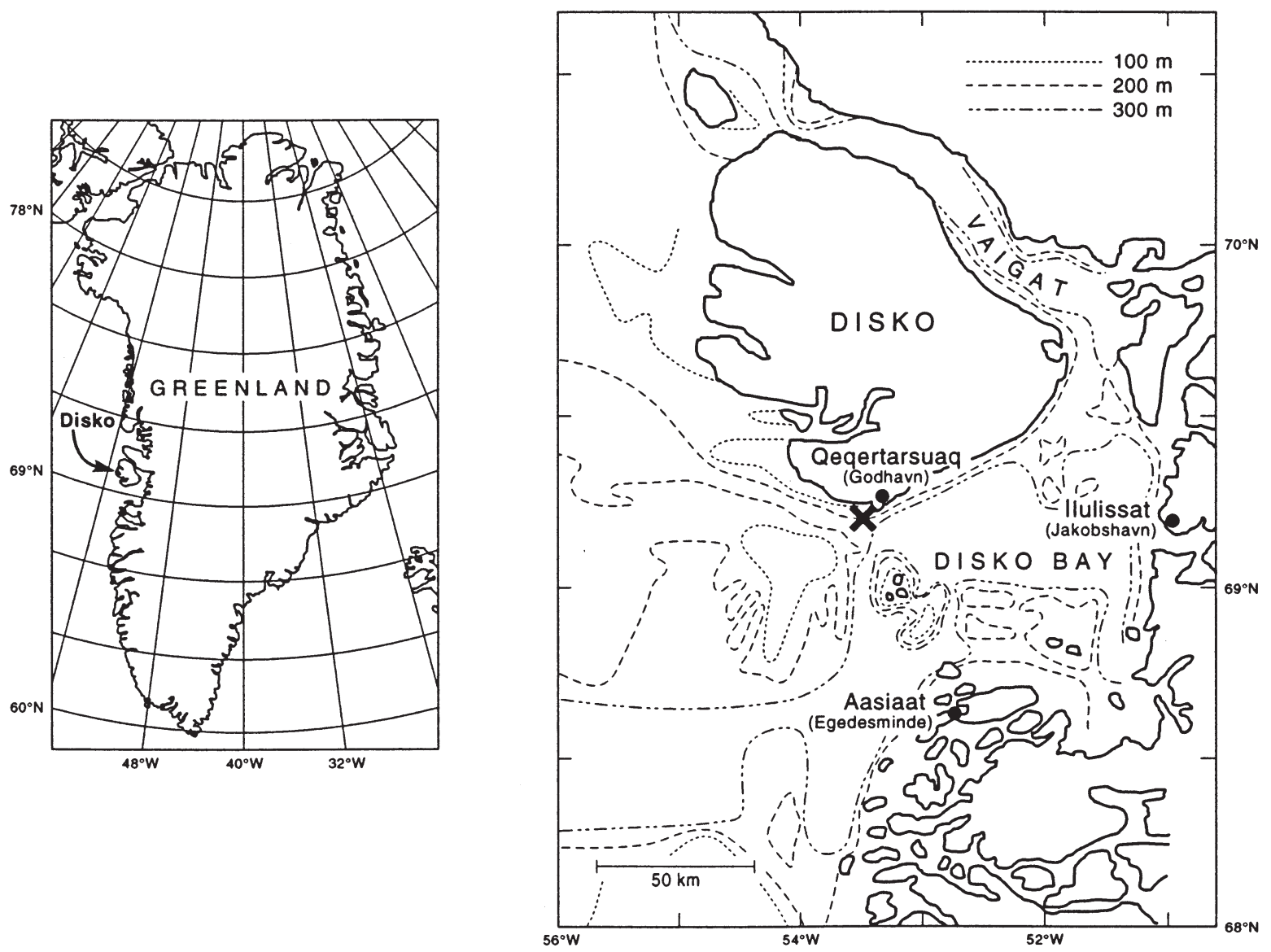

Fig. 1. Approximate position of the $250 \mathrm{~m}$ deep sampling station in Disko Bay 
centration of algae living within and immediately below the sea ice.

Phytoplankton. Chlorophyll a (chl a) concentrations in water from all depths were measured spectrophotometrically (Strickland \& Parsons 1972) after filtering 3 to 151 of seawater onto GF/F filters and extracting in $96 \%$ ethanol over night (Jespersen \& Christoffersen 1987). Phytoplankton carbon biomass of all nano- and micro-sized cells from $2 \mathrm{~m}$ depth and from the depth of the fluorescence maximum was estimated based on $2 \%$ final concentration (v/v) Lugol's-preserved samples analyzed with an inverted microscope (H. A. Thomsen unpubl. data). Autotrophic and heterotrophic flagellates $<20 \mu \mathrm{m}$, which were considered primary prey for ciliates, were also counted by epifluorescence microscopy of proflavine stained filters (Haas 1982). Samples were preserved with glutaraldehyde to a final concentration of $1 \%$. A volume-specific carbon weight of $0.13 \mathrm{pg} \mathrm{C} \mathrm{Hm}^{-3}$ was used for both Lugol's-preserved and glutaraldehyde-preserved cells (Hansen et al. 1997).

Ciliates and heterotrophic dinoflagellates. Water samples of $325 \mathrm{ml}$ were, as phytoplankton, preserved in acid Lugol's solution immediately and stored in the dark until examination with an inverted microscope. Samples $(325 \mathrm{ml})$ from $2 \mathrm{~m}$ and the chl a fluorescence maximum were also preserved in a buffered aldehyde mixture for subsequent epifluorescence microscopy (see Levinsen et al. 1999).

Biomass was estimated in Lugol's-preserved water from $2 \mathrm{~m}$, the chl a fluorescence maximum (or $15 \mathrm{~m}$ ) and $30 \mathrm{~m}$. Depending on water column structure and chlorophyll fluorescence distribution, additional samples were occasionally analyzed. On the monthly intensive sampling days, the biomass from 8 to 9 depths between 2 and $200 \mathrm{~m}$ was determined. Organisms in 50 to $325 \mathrm{ml}$ aliquots were settled and counted. Winter and deep-water samples with low cell concentrations were pre-settled for a week prior to the removal of the supernatant by siphoning and a final sedimentation of the remaining $100 \mathrm{ml}$. The supernatant contained an insignificant number of small cells $(<5 \%$ of settled cells). Surface samples were counted within a week, the other samples were processed after 6 mo.

Cells were identified and measured using the criteria outlined in Levinsen et al. (1999) and converted from biovolume to units of carbon using a conversion

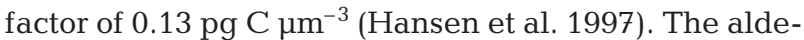
hyde-preserved samples intended for trophic separation of dinoflagellates were settled in the dark in a refrigerator and counted on an inverted microscope equipped with a $100 \mathrm{~W}$ mercury lamp within $2 \mathrm{~d}$ of sampling. A ratio between autotrophic (pigmented) and heterotrophic dinoflagellates was calculated for unidentifiable spherical to subspherical gymnodinoid forms in size groups of $10 \mu \mathrm{m}$ starting with an equiva- lent spherical diameter (ESD) of 20 to $30 \mu \mathrm{m}$. At least 75 cells were inspected. Heterotrophic dinoflagellate biomass was estimated by multiplication of the autotrophic/heterotrophic cell ratio with the cell concentrations from similar size groups determined from Lugol's counts. During winter, when the cells were scarce, a mean of ratios obtained from 2 sampling dates in the late autumn was applied. The method did not allow for separation between mixotrophic and autotrophic dinoflagellates. Possibly, some cells categorized as autotrophic were mixotrophic. However, the epifluorescence samples were used to distinguish mixotrophic from heterotrophic ciliates. Uniformly red-orange fluorescent cells were considered mixotrophic and green cells heterotrophic. Cells were divided in size classes of $10 \mu \mathrm{m}$ based on length. At least 75 ciliates were counted per sample. For both ciliates and dinoflagellates it was assumed that heterotrophic, mixotrophic and autotrophic cells were preserved equally well.

By 'oligotrichous ciliates' we refer to the subclass Oligotrichia that include the ciliate orders Choreotrichida and Oligotrichida (Lynn \& Corliss 1991). Biomass per $\mathrm{m}^{2}$ was calculated by trapezoidal integration over the depth strata 0 to $200 \mathrm{~m}$ (Nielsen \& Bresta 1984). A linear interpolation from the temporally nearest corresponding depths was used to estimate the biomass at 50, 100 and $200 \mathrm{~m}$ when these depths were not sampled. Because the proportion of unidentified autotrophic gymnodinoids was not established at all depths, we present integrated heterotrophic dinoflagellates as 'total' values, excluding only the autotrophic species recognized from the Lugol's counts. This was preferred over the use of interpolation of the established autotrophic/heterotrophic dinoflagellate ratios between samples as these ratios were found to vary unpredictably with depth and time. Thus, depthintegrated values are slightly overestimated and strict heterotrophic dinoflagellates are presented for the surface water and fluorescence maximum depth only.

Growth and mortality. Net growth and loss rates were calculated for spring, summer and autumn-winter communities as the slope of the regression line fitted to ln transformed biomass values versus time assuming exponential biomass changes. Data points for the regressions were selected using stepwise analysis to get the best fit to the model; at each step a Pearson correlation coefficient was calculated and the significance of the correlation was determined by a $t$-test.

Diversity. Margalef's index (Margalef 1951) was used to show the seasonal pattern in ciliate and heterotrophic dinoflagellate diversity. This index $\left(I_{\mathrm{m}}\right)$ suggests a simple logarithmic relationship between number of species $(S)$ and individuals $(N): I_{\mathrm{m}}=(\mathrm{S}-1) / \log N$. We used the identified morphospecies as the 'species concept' to calculate the index. 


\section{RESULTS}

\section{Hydrography, ice and meteorological conditions}

High seasonal variation in solar irradiance characterizes the study site. Polar darkness occurs from late November to late January (Fig. 2a). Snow-covered annual sea ice further lengthens the period with reduced light penetration into the water (Fig. 2b). In 1996, the sea ice broke up on April 26. In 1997, ice formation started in February but due to strong wind episodes, fast ice first developed in March. The fast ice cover lasted until late April. Thereafter it broke up and drifted in Disko Bay for several weeks as in the previous year. Sub-zero temperatures characterized the surface water from late November until May-June (Fig. 2b). An annual temperature maximum of $\sim 6^{\circ} \mathrm{C}$ was recorded in August.

The water column experienced an annual pattern in structure and stability essentially consisting of 2 elements corresponding to the productive summer period and the unproductive winter period (Fig. 2c). After

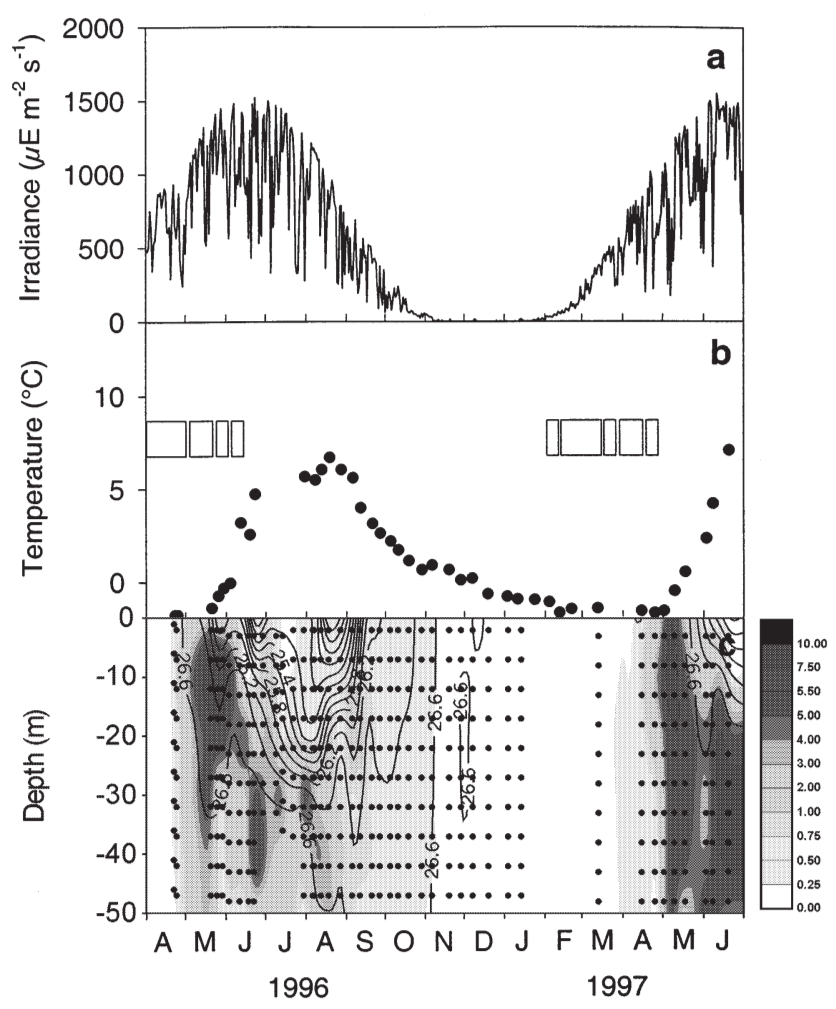

Fig. 2. (a) Annual variations of daily averages in solar irradiance (photosynthetically active radiation, PAR) calculated from measurements conducted every $30 \mathrm{~min}$. (b) Ice cover (boxes) and water temperature at $2 \mathrm{~m}$. The vertical breaks in the boxes indicate approximately when temporary breaks in the ice cover occurred. (c) Vertical distribution of chlorophyll a $\mathrm{l}^{-1}$ (shaded area) and water density $\left(\mathrm{kg}+1000 \mathrm{~m}^{-3}\right.$ ) calculated from salinity and temperature measurements (dots) from the upper $50 \mathrm{~m}$ of the water column ice-breakup melt water and solar heating formed a warmer less-dense surface layer. This stratification strengthened and deepened during summer. In the beginning of May 1996 the 33.0 PSU isoline was located near the surface; in August it was at $30 \pm 1 \mathrm{~m}$ (mean $\pm \mathrm{SD}$ of 5 station visits). The mean temperature in the upper $5 \mathrm{~m}$ during this period increased from $<-1.7$ to $5.9 \pm 0.4^{\circ} \mathrm{C}$. Following the stratified summer conditions there was a short transition to mixed winter conditions in September (Fig. 2c). Increased wind and reduced daylength resulted in the development of an upper water column with a more-or-less uniform distribution of salinity and temperature and hence density. The mixed water column conditions lasted until the ice breakup in spring 1997.

\section{Annual succession of auto- and heterotrophs}

We sampled a complete annual succession of plankton from April 1996 to April 1997 and the beginning of a second succession cycle with the biomass build-up in May through June 1997.

\section{Phytoplankton}

Prior to May 4 the phytoplankton biomass was low (Fig. 2c). The chl $a$ in the upper $30 \mathrm{~m}$ of the water column was $0.2 \pm 0.1 \mu \mathrm{g}^{-1}$. Between May 4 and the subsequent sampling on May 20, a spring bloom developed and chl a increased to $5.9 \pm 1.2 \mu \mathrm{g} \mathrm{l}^{-1}$. Phaeocystis sp., chainforming centric diatoms of the genus Thalassiosira, Detonula confervaceae, and pennate diatoms dominated this bloom. After the bloom the phytoplankton surface community changed, and nanoflagellates became more abundant than diatoms. In the pycnocline, diatoms (Chaetoceros spp.) remained dominant most of the summer, where they formed a subsurface bloom. The annual development of integrated phytoplankton biomass showed increasingly higher levels after the main spring bloom and following summer minimum, reflecting this summer subsurface bloom (Fig. 3a). The bloom persisted until August, when a second phytoplancton peak occurred. During the autumn-winter transition chl a gradually declined to a minimum of $0.11 \pm 0.07 \mu \mathrm{g} \mathrm{l}^{-1}$ in the upper $30 \mathrm{~m}$ between November and March. Winter chl a concentrations corresponded to deep water levels during summer.

Following the break-up of the sea ice, the phytoplankton developed again during late April and peaked in mid-May. The integrated phytoplankton spring bloom biomass recorded in 1997 was nearly twice the biomass of 1996. This reflects the fact that the bloom peaked between 2 samplings in May 1996, as 
verified by the depletion in the concentration of nitrate. The dominant bloom forming phytoplankton species in 1997 were similar to those observed in 1996 (H. A. Thomsen unpubl. data).

\section{Ice algae}

Pennate diatoms accumulating at the bottom of the sea ice prior to the spring phytoplankton bloom dramatically increased the algal biomass in April (Fig. 3a). The mean net ice algal growth rate in 1997 was $0.11 \mathrm{~d}^{-1}$. On April 15 the chl a concentration peaked at $184 \pm 76 \mu \mathrm{g} \mathrm{l}^{-1}$ in the bottom $\sim 1 \mathrm{~cm}$ of the ice $(\mathrm{n}=3)$. The ice algae biomass declined during the last 2 sampling occasions before ice breakup. At the ice-water
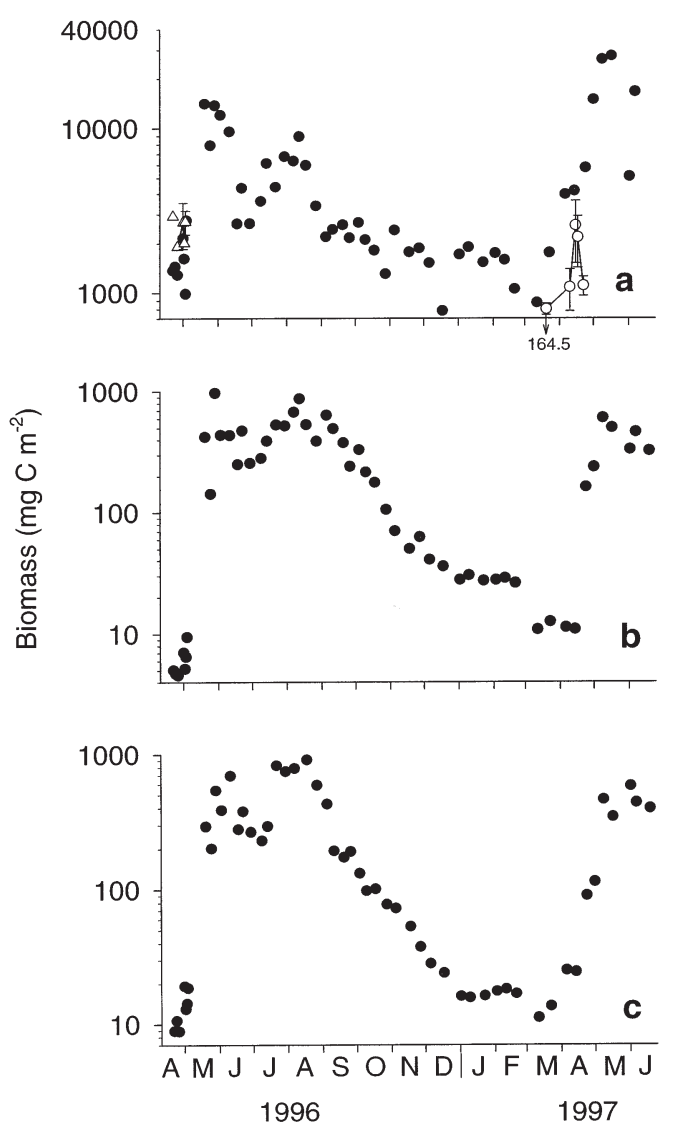

Fig. 3. Annual integrated ( 0 to $200 \mathrm{~m}$ ) biomass pattern of (a) phytoplankton estimated from carbon-chlorophyll a ratios of 38, 44 and 109 obtained for spring, post-bloom/summer and winter communities, respectively, (b) ciliates excluding Myrionecta rubra and (c) heterotrophic dinoflagellates. In (c), a single biomass value of $1405 \mathrm{mg} \mathrm{C} \mathrm{m}{ }^{-2}$ on August 12 is not depicted. The mean concentrations of primary producers $\left(\mu \mathrm{g} \mathrm{C} \mathrm{l}^{-1}\right.$ ) within the bottom $\sim 1 \mathrm{~cm}$ of sea ice in spring 1996 and 1997 are shown as open symbols in (a). Error bars mark \pm SD of triplicates. Data from April 22 to May 5, 1996, are from Grastrup-Hansen (1998). Note logarithmic scales interface, chl a displayed a similar trend, delayed a few days in comparison with the ice algae (data not shown). Here the mean growth rate was $0.17 \mathrm{~d}^{-1}$. Maximum chl a concentration at the ice-water interface was $13 \mu \mathrm{g} \mathrm{l}^{-1}$, which is comparable to the phytoplankton bloom maximum of $14 \mu \mathrm{g}$ chl a $\mathrm{l}^{-1}$ recorded a month later. However, the integrated ice algal biomass was only $\sim 10 \%$ of the pelagic phytoplankton biomass.

\section{Protozoa}

The bimodal seasonality of the primary producers was reflected in the biomass patterns of protozoa, which ranged over 3 orders of magnitude from winter to summer (Fig. 3b,c). In late winter the integrated community biomass ( 0 to $200 \mathrm{~m}$ ) for both ciliates and heterotrophic dinoflagellates was $\sim 10 \mathrm{mg} \mathrm{C} \mathrm{m}^{-2}$. The spring biomass increase followed the ice-breakupinduced phytoplankton bloom initiated in April-May with only a short time lag, on the order of days. A typical summer community was established by the end of May. In August the ciliate and heterotrophic dinoflagellate biomasses reached a second peak corresponding to annual maxima of $620 \pm 206$ and $910 \pm 347 \mathrm{mg} \mathrm{C}$ $\mathrm{m}^{-2}$, respectively (mean $\pm \mathrm{SD}$ of 4 samplings). Heterotrophic dinoflagellate biomass subsequently declined at a constant rate; ciliate biomass declined 3 wk later. The annual minimum was reached in January. Winter levels of protozoan biomass remained low until April.

Table 1. Net community growth and loss (mortality + respiration) rates $\left(\mu \mathrm{d}^{-1}\right)$ at $2 \mathrm{~m}$ depth of chlorophyll $a$, phytoplankton, total ciliates (excluding Myrionecta rubra) and heterotrophic dinoflagellates assuming exponential growth. First number in parenthesis: $\mathrm{r}^{2}$ of the regression line fitted to the data points representing the exponential model; second number in parenthesis: $\mathrm{n}$, the number of data points included in the model; see 'Methods: Growth and mortality'; -: No data

\begin{tabular}{|c|c|c|c|c|}
\hline & $\begin{array}{l}\text { Spring } \\
1996\end{array}$ & $\begin{array}{l}\text { Summer } \\
1996\end{array}$ & $\begin{array}{l}\text { Autumn } \\
1996\end{array}$ & $\begin{array}{l}\text { Spring } \\
1997\end{array}$ \\
\hline Chlorophyll a & $\begin{array}{c}0.09 \\
(0.80 ; 11)\end{array}$ & $\begin{array}{c}0.01 \\
(0.73 ; 18)\end{array}$ & $\begin{array}{l}-0.05 \\
(0.91 ; 7)\end{array}$ & $\begin{array}{c}0.09 \\
(0.90 ; 8)\end{array}$ \\
\hline Phytoplankton & - & $\begin{array}{c}0.00 \\
(0.16 ; 10)\end{array}$ & $\begin{array}{c}-0.04 \\
(0.89 ; 7)\end{array}$ & $\begin{array}{c}0.11 \\
(0.94 ; 6)\end{array}$ \\
\hline Ciliates & $\begin{array}{c}0.15 \\
(0.88 ; 12)\end{array}$ & $\begin{array}{c}0.00 \\
(0.11 ; 17)\end{array}$ & $\begin{array}{c}-0.04^{\mathrm{a}} \\
(0.84 ; 11)\end{array}$ & $\begin{array}{c}0.07 \\
(0.79 ; 10)\end{array}$ \\
\hline $\begin{array}{l}\text { Heterotrophic } \\
\text { dinoflagellates }\end{array}$ & $\begin{array}{c}0.12 \\
(0.87 ; 12)\end{array}$ & $\begin{array}{c}0.01 \\
(0.24 ; 8)\end{array}$ & $\begin{array}{c}-0.05 \\
(0.94 ; 15)\end{array}$ & $\begin{array}{c}0.08 \\
(0.94 ; 10)\end{array}$ \\
\hline \multicolumn{5}{|c|}{$\begin{array}{l}\text { a This value covers } 2 \text { periods with different mortality rates. } \\
\text { From October } 18 \text { to November } 18,1996, \mu=-0.1\left(\mathrm{r}^{2}=0.98,\right. \\
\mathrm{n}=4) ; \text { from November } 27,1996 \text { to February } 3,1997, \\
\mu=-0.03\left(\mathrm{r}^{2}=0.83, \mathrm{n}=7\right)\end{array}$} \\
\hline
\end{tabular}



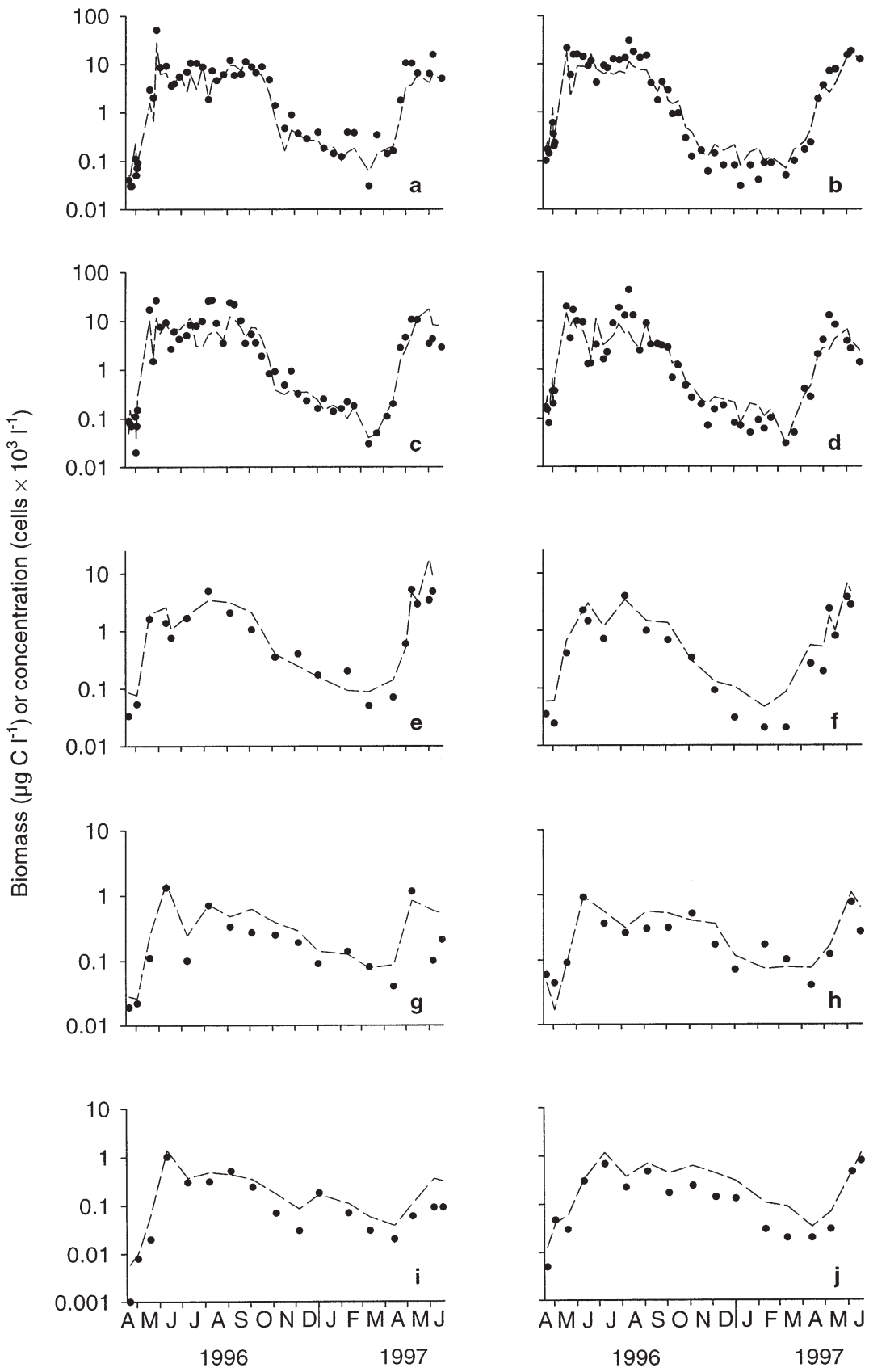

Fig. 4. Annual patterns of ciliates (excluding Myrionecta rubra) (left panels) and heterotrophic dinoflagellates (right panels) at $(\mathrm{a}, \mathrm{b}) 2 \mathrm{~m},(\mathrm{c}, \mathrm{d})$ the fluorescence maximum depth, $(\mathrm{e}, \mathrm{f}) 50 \mathrm{~m},(\mathrm{~g}, \mathrm{~h}) 100 \mathrm{~m}$ and $(\mathrm{i}, \mathrm{j}) 200 \mathrm{~m}$. (•) Biomass; (---) concentration. Data from April 22 to May 5, 1996, are from Grastrup-Hansen (1998). Note logarithmic scales

Similar seasonal abundance and biomass patterns were observed in all depth strata investigated (Fig. $4 \mathrm{a}-\mathrm{j}$ ). At $2 \mathrm{~m}$ and the depth of fluorescence maximum, or $15 \mathrm{~m}$, both ciliate and heterotrophic dinoflagellate biomasses were on the order of $0.1 \mu \mathrm{g} \mathrm{Cl}^{-1}$ during winter and $10 \mu \mathrm{g} \mathrm{Cl}^{-1}$ during summer. Cell concentations were $<<1 \times 10^{3}$ and $1-10 \times 10^{3} \mathrm{l}^{-1}$, respec- tively, during these seasons. Below the euphotic zone, the abundance and biomass levels were approximately an order of magnitude lower; here the seasonal amplitude was dampened but otherwise followed the same pattern as at the surface (Fig. 4e-j).

In spring, net community growth rates at $2 \mathrm{~m}$ for the 2 protozoan groups of 0.07 to $0.08 \mathrm{~d}^{-1}$ were only slightly lower than the growth rates of their phytoplankton prey, which was 0.09 to $0.11 \mathrm{~d}^{-1}$ (Table 1). The net mortality calculated for the protozoan communities at $2 \mathrm{~m}$ during autumn 1996 corresponded to a loss of 4 to $5 \%$ of the biomass per day equal to that of phytoplankton (Table 1).

\section{Species diversity and succession}

Naked oligotrichous ciliates (Strombidium, Strobilidium, Lohmaniella, Laboea, Tontonia spp.) and athecate, gymnodinoid dinoflagellates (Gymnodinium, Gyrodinium spp.) were the most abundant protozoans. Tintinnids and thecate dinoflagellates were less numerous. Usually $<10 \%$ of the total integrated ciliate biomass was tintinnids. Thecate heterotrophic dinoflagellates, mostly Protoperidinium spp. and species of the 'Diplopsalis group', also contributed $<10 \%$ of the heterotrophic dinoflagellates during summer, but they accounted for between 10 and $60 \%$ of the biomass during the autumn-winter period. In addition to oligotrichous ciliates and tintinnids, other ciliates were present (e.g. Didinium sp.), but they comprised an insignificant fraction of total ciliate abundance and biomass. An exception was Balanion sp., which at times were abundant, obtaining maximum concentrations of $2.5 \times 10^{3} \mathrm{l}^{-1}$ ( $35 \%$ of total number of ciliates). In terms of biomass this corresponds to $10 \%$ of the total ciliates.

The annual successions of selected protozoans showed that each species had 1 or 2 peaks of occurrence of different amplitude and duration (Fig. 5). Peaks ranged from $\sim 5 \mathrm{mg} \mathrm{C} \mathrm{m}^{-2}$ for the small dinoflagellate Amphidinium sphenoides to $\sim 900 \mathrm{mg} \mathrm{C} \mathrm{m}^{-2}$ for the large dinoflagellate Gyrodinium spirale. Among the ciliates Laboea strobila obtained the highest bio- 

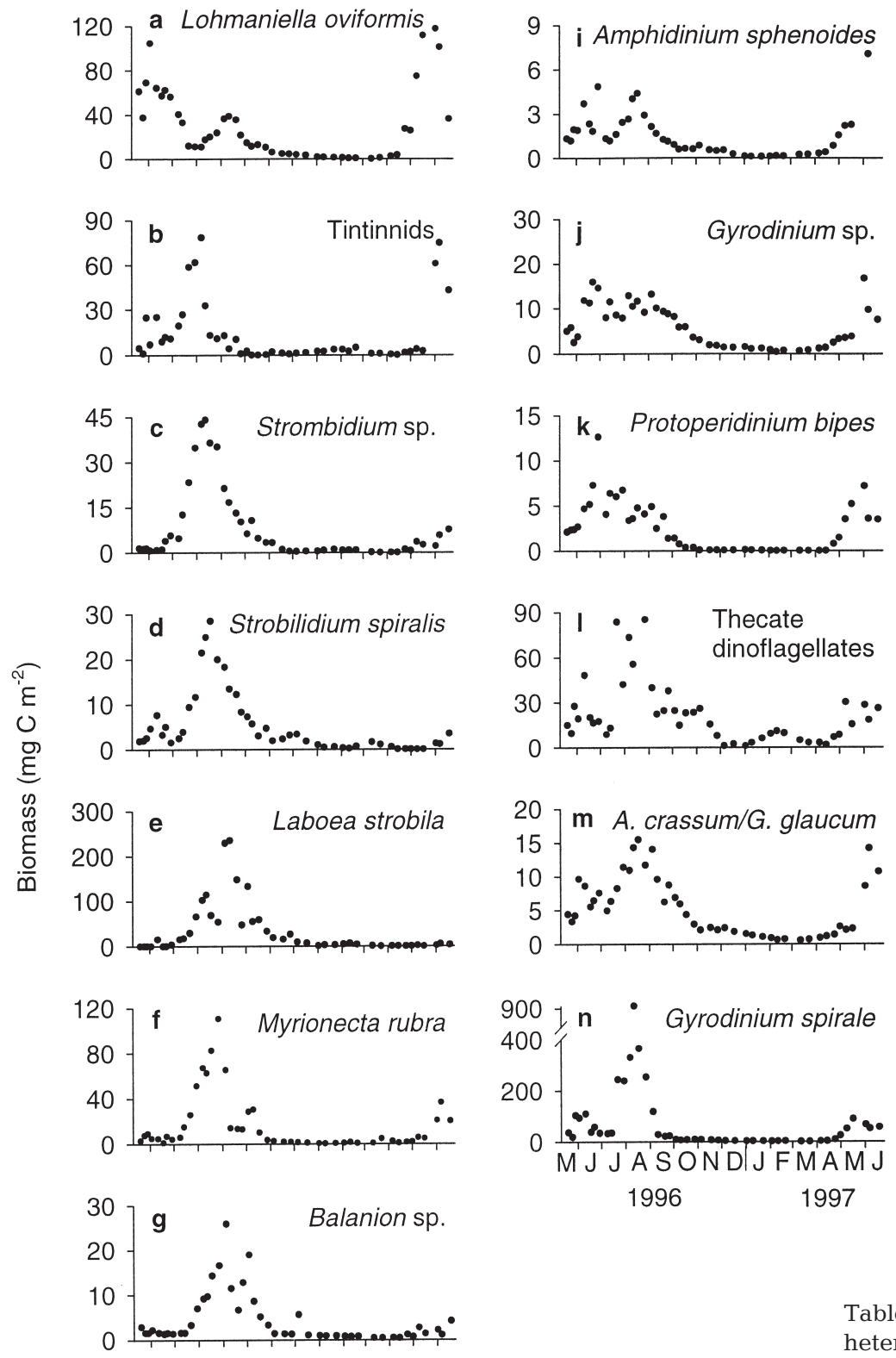

mass, $235 \mathrm{mg} \mathrm{C} \mathrm{m}{ }^{-2}$. The autotrophic ciliate Myrionecta rubra had a maximum of $110 \mathrm{mg} \mathrm{C}$ $\mathrm{m}^{-2}$, which corresponds to $\sim 20 \%$ of the total integrated ciliate biomass. On average this species contributed $5 \%$.

Protozoan species richness was lowest during the winter and highest in the summer (Fig. 6a,c), but when corrected for differences in sample size the seasonality in species diversity was less pronounced (Fig. 6b,d). Winter diversity did not change significantly from that in summer (ANOVA, p > 0.05), although heterotrophic dinoflagellates showed a tendency to decline during the late autumn.

The seasonal distribution of cell size of the 2 protozoan communities differed (Table 2). While the mean ciliate volume did not change, winter dinoflagellates were smaller than summer cells. In deep-water samples, protozoans were small throughout the year.

Gyrodinium spirale showed the typical size pattern for dinoflagellates (Fig. $7 \mathrm{c}, \mathrm{d}$ ). Small individuals occurred during winter and large cells during the summer, associated with the diatom subsurface bloom (Fig. 7d). Myrionecta rubra also demonstrated a pronounced seasonal variation in volume (Fig. 7a,b). Thus, on the species level the trend of this ciliate contrasted the temporal size variation on the community level.

Mixotrophic ciliates were recorded even in winter and during summer they dominated, accounting for 45 to $85 \%$ of the total oligotrichous ciliate numbers at $2 \mathrm{~m}$ (Fig. 8). Division of oligotrichs into the size groups 'small' $(<30 \mu \mathrm{m})$,

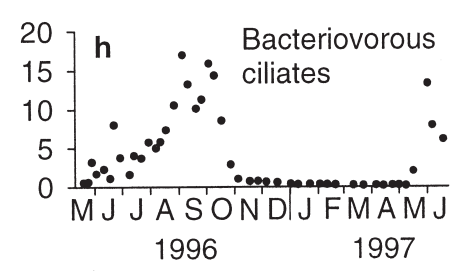

Fig. 5. Annual succession of selected species and groups of $(\mathrm{a}-\mathrm{h})$ ciliates and $(\mathrm{i}-\mathrm{n})$ heterotrophic dinoflagellates in Disko Bay from April 1996 to June 1997 (integrated from 0 to $200 \mathrm{~m}$ ). 'Tintinnids' were represented by a few species with hyaline loricas such as Parafavella denticulata and Ptychocylis obtusa, 'bacterivorous ciliates' were small oligotrichs (length $<20 \mu \mathrm{m}$ ) and the most common 'thecate dinoflagellates' (heterotrophic) belonged to the genus Protoperidinium and the 'Diplopsalis group'
Table 2. Mean summer and winter volumes of ciliates and heterotrophic dinoflagellates $\left(\mu^{3} \times 10^{3} \pm \mathrm{SD}\right)$. FM = depth of fluorescence maximum, numbers in parenthesis refer to samples (n)

\begin{tabular}{|ccccc|}
\hline \multirow{2}{*}{$\begin{array}{c}\text { Depth } \\
(\mathrm{m})\end{array}$} & \multicolumn{2}{c}{ Ciliates } & \multicolumn{2}{c|}{ Dinoflagellates } \\
\hline 2 & Summer & Winter & Summer & Winter \\
& $13.9 \pm 6.3$ & $12.3 \pm 5.7$ & $13.8 \pm 8.4$ & $5.2 \pm 1.9$ \\
& $(31)$ & $(15)$ & $(31)$ & $(15)$ \\
FM & $12.1 \pm 9.7$ & $10.7 \pm 5.3$ & $13.1 \pm 12.9$ & $5.8 \pm 2.4$ \\
& $(31)$ & $(15)$ & $(31)$ & $(15)$ \\
50 & $7.3 \pm 3.4$ & $10.1 \pm 5.5$ & $6.5 \pm 2.7$ & $4.8 \pm 2.9$ \\
& $(12)$ & $(6)$ & $(12)$ & $(6)$ \\
100 & $5.8 \pm 3.3$ & $6.9 \pm 2.3$ & $6.4 \pm 1.6$ & $9.2 \pm 5.7$ \\
& $(9)$ & $(6)$ & $(9)$ & $(6)$ \\
200 & $5.4 \pm 2.6$ & $5.1 \pm 2.0$ & $5.7 \pm 1.7$ & $3.5 \pm 1.4$ \\
& $(9)$ & $(6)$ & $(9)$ & $(6)$ \\
& & & & \\
\hline
\end{tabular}



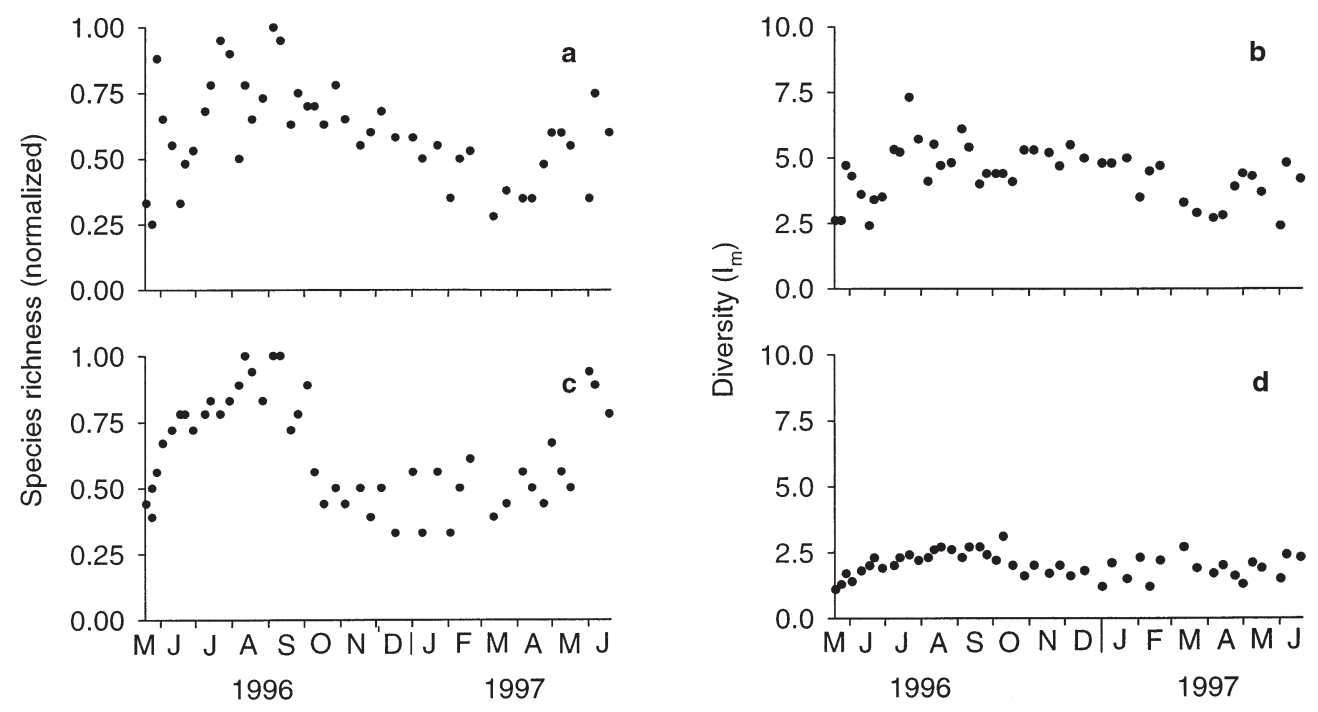

Fig. 6. Species richness $(S)$ normalized to maximum, and Margalef's species diversity index $\left(I_{\mathrm{m}}\right)$ of $(\mathrm{a}, \mathrm{b})$ ciliates and $(\mathrm{c}, \mathrm{d})$ heterotrophic dinoflagellates at $2 \mathrm{~m}$ depth. $\left[I_{\mathrm{m}}=(S-1) /(\mathrm{lnN})\right]$

'medium' (30 to $50 \mu \mathrm{m})$ and 'large' (>50 $\mu \mathrm{m})$ showed that mixotrophy dominated in all size classes (ANOVA, $\mathrm{p}<0.05)$. Thus, the probability that an oligotrich was mixotrophic was larger than the probability that it was heterotrophic. However, all ciliates $<20 \mu \mathrm{m}$ were heterotrophic. The same seasonality as observed at $2 \mathrm{~m}$ depth was found in subsurface waters, although the overall contribution of mixotrophs was lower. column structure are mainly determined by differences in the extent of melt water. Stratification is established when Disko Bay receives a large freshwater input of melting snow and ice in early summer. These melting processes result in surface water that flows out of the Bay (e.g. Andersen 1981). Advection thus influences our sampling station. Nonetheless, during horizontal surveys in Disko Bay in June-July 1996 and June 1997 we observed that the general pattern in plankton succession was similar on a larger scale (P. Munk et al. unpubl. data). For the purpose of this discussion, we assume that our sampling station represents the annual plankton succession in the Bay.
This study emphasizes that pelagic protozoans are essential components of the Arctic pelagic food web during the summer period. It also provides new information on winter plankton dynamics. A diverse but dilute protozoan community was present throughout the winter. This observation is corroborated by extensive sampling and it enables us to hypothesize on pelagic heterotrophic protistan overwintering strategies in a system where phytoplankton production is low or zero during several months each year.

\section{Annual dynamics and composition}

Disko Bay experiences great fluctuations in the degree of ice cover from year to year. In the winter of 1996/97, sea ice was formed late due to mild weather conditions. Seasonal changes in the water
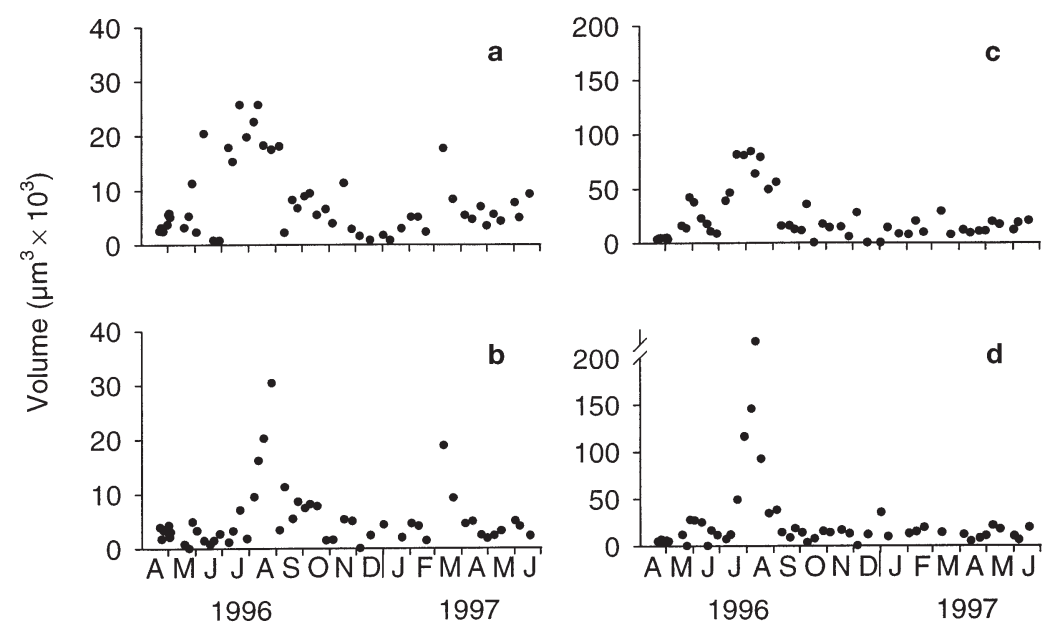

Fig. 7. Seasonal variations in the mean cell volume of $(a, b)$ Myrionecta rubra and $(\mathrm{c}, \mathrm{d})$ Gyrodinium spirale, $(\mathrm{a}, \mathrm{c})$ at $2 \mathrm{~m}$ depth and $(\mathrm{b}, \mathrm{d})$ at the depth of the fluorescence maximum 


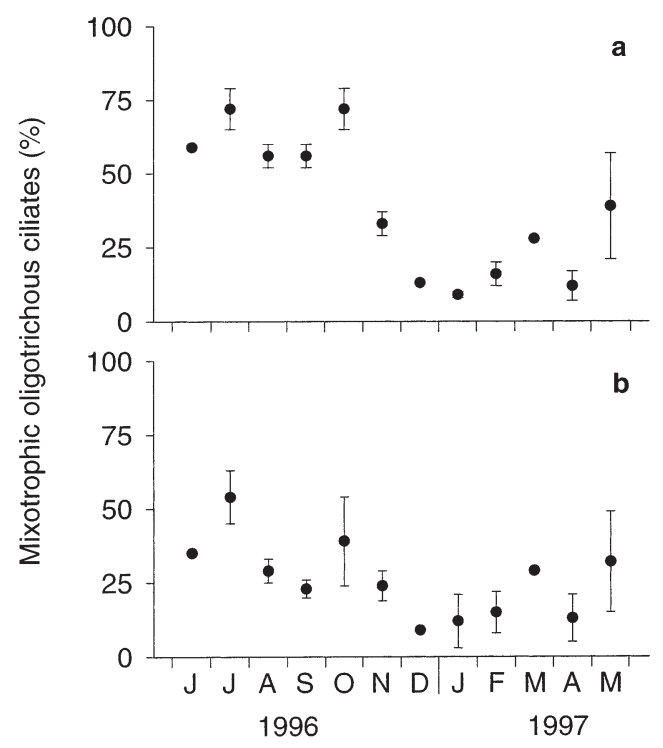

Fig. 8. Seasonal contribution of mixotrophs to total abundance of oligotrichous ciliates (\%) at (a) $2 \mathrm{~m}$ depth and (b) the depth of fluorescence maximum, or $15 \mathrm{~m}$, shown as monthly means $\pm \mathrm{SD}$

The protozoan community in Disko Bay showed a strong seasonal signal in biomass. The winter values are among the lowest ever reported for marine waters (Garrison et al. 1993, Scharek et al. 1994, Boyd et al. 1995, Sherr et al. 1997). The summer protozoan concentrations, in contrast, were as high as those reported for neritic, temperate marine waters (Hansen 1991, Pierce \& Turner 1992). Key species were the ciliate Laboea strobila and the heterotrophic dinoflagellate Gyrodinium spirale. This agrees with data from the same sampling station collected during summer 1994 (Levinsen et al. 1999).

Ciliates and heterotrophic dinoflagellates revealed a similar temporal pattern with one peak in late Mayearly June and another in August. Such a pattern is different from the unimodal pattern found for ciliates in Antarctic coastal waters (Leakey et al. 1994), although the difference may reflect a lower temporal and spatial sampling frequency in the Antarctic study. Bimodality in protozoan biomass is found also in temperate waters; here peaks co-occur with the spring and autumn phytoplankton blooms (Smetacek 1981, Nielsen \& Kiørboe 1994). Thus, on an annual scale, these patterns from different latitudes demonstrate a tight trophic coupling between phytoplankton and protozoan grazers. The pattern of protozoans from Disko Bay, however, contrasts with the classical idea that the primary productivity cycle in the Arctic consists of a single peak connected to the ice-break (Smith \& Sakshaug 1990).

Heterotrophic dinoflagellates, primarily athecate species, frequently dominated spring and summer as re- ported for temperate (Smetacek 1981), tropical (Verity et al. 1996), Antarctic (Bjørnsen \& Kuparinen 1991) and Artic marine waters (Nielsen \& Hansen 1995). Compared to mesozooplankton heterotrophic dinoflagellates can respond quickly to episodic diatom blooms. Obviously, carbon flow studies that do not include this group of organisms are not complete.

The majority of the ciliates were mixotrophic. This confirms several other studies where plastidic oligotrichs have been found to be ubiquitous and important components of surface plankton communities (Stoecker et al. 1989, Putt 1990, Bernard \& Rassoulzadegan 1994). Unexpectedly, mixotrophs were also observed in high proportions during winter $(18 \%)$. Even Laboea strobila, which is considered an obligate mixotrophic ciliate (Stoecker et al. 1988), was recorded during the dark winter months, as was the autotrophic ciliate Myrionecta rubra (Fig. 9). Apparently, the dependence on photosynthesis for growth does not prevent individuals of these species from surviving periods without light.

\section{Overwintering strategy}

Dormancy and overwintering in copepods have been studied extensively (Conover \& Siferd 1993, Dahms 1995, Hirche 1996) and dark survival strategies in

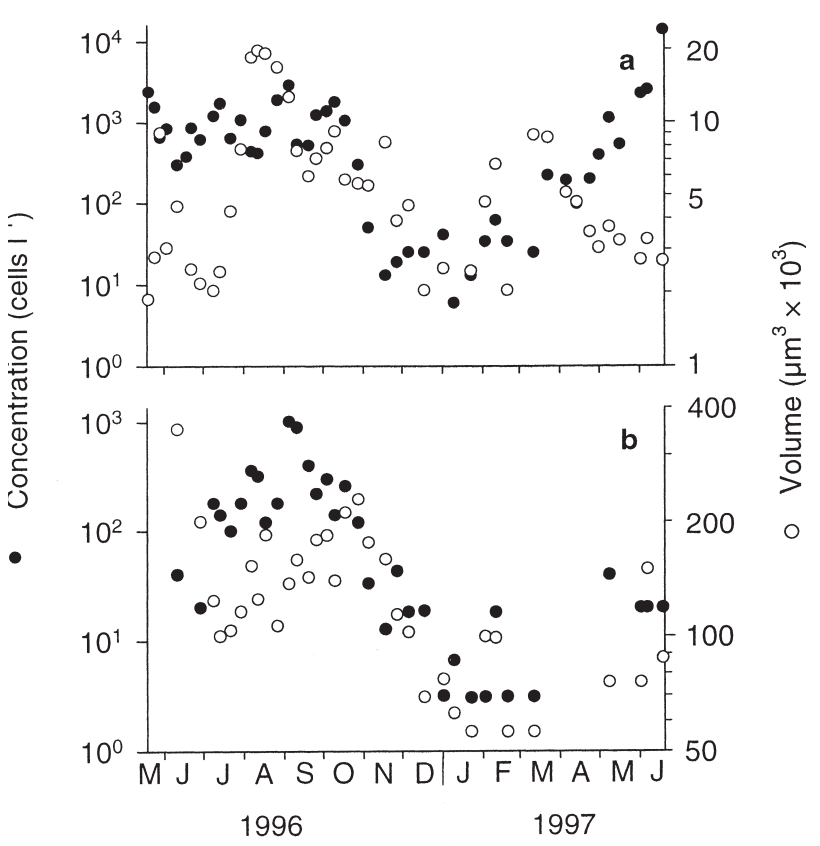

Fig. 9. Maximum concentrations and mean cell volumes (logarithmic scales) of the 2 'obligate' auto-/mixotrophic ciliate species (a) Myrionecta rubra and (b) Laboea strobila. Note their occurrence throughout winter 


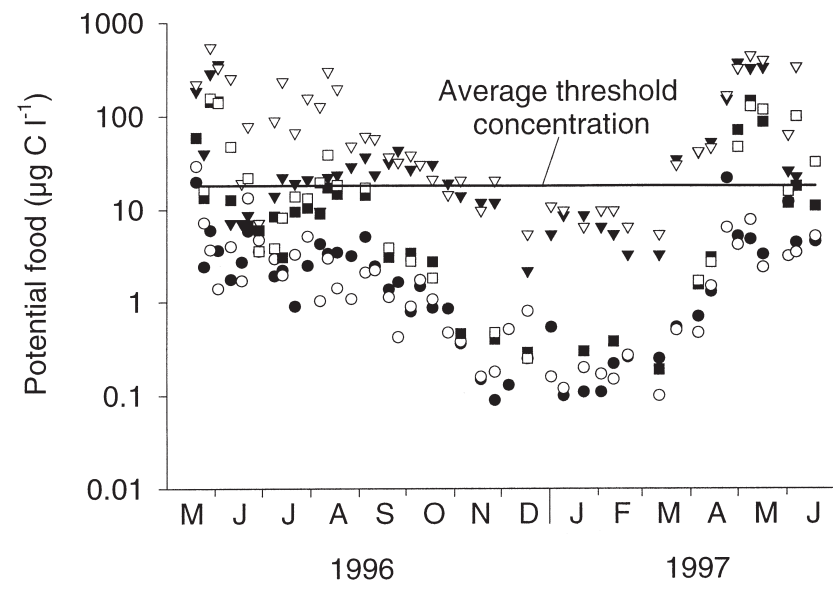

Fig. 10. Seasonal variations in the concentrations of potential food for ciliates and heterotrophic dinoflagellates. $(0, \bullet)$ Autotrophic and heterotrophic nanoflagellate carbon biomass estimated using epifluorescence microscopy; $(\square, \boldsymbol{\square})>2 \mu \mathrm{m}$ phytoplankton carbon biomass determined using inverted microscopy (H. A. Thomsen unpubl.); $(\nabla, \boldsymbol{\nabla})$ total phytoplankton biomass calculated from obtained carbon-chlorophyll a ratios (see Fig. 3 legend). Closed symbols: depth of fluorescence maximum; open symbols: $2 \mathrm{~m}$. Horizontal line: mean threshold concentration for growth of ciliates and heterotrophic dinoflagellates based on 21 measurements collected from the literature by Jacobsen \& Hansen (1997) after excluding 4 unusually high values. This threshold concentration, where growth rate equals zero, corresponds to $18 \pm 18 \mu \mathrm{g} \mathrm{Cl}^{-1}$ (range 6 to 75$)$. Note logarithmic scales

phytoplankton have also received attention (Fryxell 1983, Jochem 1999). Much less is known about the strategies used by protozoans to cope with adverse food conditions. Laboratory studies report rapid mortality of starving ciliates, where all cells die during a few days (Fenchel \& Jonsson 1988, Nielsen et al. 1990, Stoecker \& Silver 1990, Wickham et al. 1993, Montagnes 1996, Jacobsen \& Hansen 1997). This is in stark contrast to the observations of protozoa in Disko Bay throughout the year. Evidently, a winter protozoan community survived several months despite the fact that food concentrations were below the threshold where the growth rate equals zero (Fig. 10). In the following, we focus on this paradox and discuss 4 overwintering strategies in order to answer the question 'How do protozoans survive the arctic winter?'

\section{(1) Allochthonous sources}

Advection of plankton from southern areas can lead to erroneous conclusions on winter surviving protozoa. Disko Bay occasionally receives Irminger Water of Atlantic origin, which flows northwards as a coastal stream. However, the stream occurs at depths much below pro- ductive layers, and further, assuming typical winter flow velocities of 20 to $25 \mathrm{~cm} \mathrm{~s}^{-1}$ (E. Buch pers. Comm.), it takes almost 2 mo for a parcel of water to move the $\sim 1000 \mathrm{~km}$ up the west Greenland coast and enter the Bay. Advected protozoa should therefore, like the protozoa in Disko Bay, be able to starve for long periods.

Sea ice is another potential source of allochthonous material. Garrison et al. (1993) suggested that input of organisms and detritus from the sea ice served as an alternative carbon source for planktonic heterotrophs in the ice-edge zone of the Weddell and Scotia Seas during the early austral winter. It is likely that, in the late spring, input from sea ice also occurred in Disko Bay, but during winter, when production in the ice was negligible, such input could not be important for sustaining pelagic protozoan communities. We conclude that allochthonous input is of temporally restricted or local importance and not a mechanism able to explain the general paradox.

\section{(2) Cyst formation}

Fenchel (1987) hypothesized that responses of protozoa reflect the time scale of fluctuations in food resources. Cells will stay active if periods of starvation are short and will encyst under extended periods of starvation. As the polar winter certainly has an extended period with low food supply, encystment would be expected. However, cysts were rarely recorded in the present study and then only of tintinnid and thecate dinoflagellate origin. The dominant naked oligotrichous ciliates and gymnodinoid dinoflagellates were never found to produce cysts. The apparent lack of resting stages might reflect (1) difficulties in detection and identification of cysts, or (2) that many pelagic protozoans do not usually produce cysts. Only 3 nontintinnid, marine oligotrichous ciliates and $\sim 5 \%$ of all dinoflagellates are known to produce resting cysts (Fauré-Fremiet 1948, Reid 1987, Kim \& Taniguchi 1995, Sonneman \& Hill 1997).

In Disko Bay steep coastal slopes limit resuspension of potential cysts from shallow water. Rather than acting as a near-surface 'inoculum' coastal cysts would be advected to deep water (up to $>800 \mathrm{~m}$ ), and likely become lost from the pelagial, if sedimenting there. At least, a fast responding protozoan community on the spring phytoplankton increase, such as the observed, would not be expected. The adaptive significance of cyst formation, therefore, seems to be small for the pelagial protozoan community of Disko Bay. We hypothesize that the most favorable overwintering strategy for planktonic protozoa involves them remaining motile in surface waters until conditions become favorable for growth. 


\section{(3) Food patchiness}

Protozoans in Disko Bay may regularly, by chance, have encountered and exploited prey patches. A generally stable field ciliate abundance in the range of 1 to $10 \times 10^{3}$ cells $1^{-1}$ may be used as an indication of the existence of prey patches because 'average' prey biomass levels often are near or below the ciliate threshold concentrations (Montagnes 1996). For > 3 mo during winter, when ciliate and heterotrophic dinoflagellate concen-

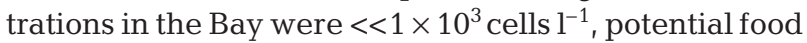
levels were much below the average threshold value for growth (Fig. 10). This suggests that if the protozoan populations survived this period based on growing individuals they relied on concentrated prey (e.g. on marine aggregates) with distances between patches that correspond to no more than the distance displaced within a protozoon lifetime. The prey enrichment should exceed the gap between the measured bulk phytoplankton concentration and the threshold concentration depicted in Fig. 10 (triangles) because many protozoons only feed on prey within a certain size spectrum (Jonsson 1986, Kivi \& Setälä 1995). Thus, not all phytoplankton cells in such a food estimate may be suitable prey. Food patchiness was not examined in this study. However, we expect that rapid aggregate degradation by presumably carbon-limited bacteria populations resulted in a depleted prey habitat within a few weeks after aggregate formation during the spring-summer period. New aggregate formations during winter would be severely limited due to low plankton concentrations.

\section{(4) Reduced winter metabolism}

The heterogeneous environment suggests that protozoa seldom experience balanced growth. Naturally, therefore, they must have developed metabolic adaptations to variations in food resources in addition to encystment. From laboratory measurements, some protozoans are known to reduce their respiration substantially at resource levels below that sustaining minimum growth (Fenchel \& Finlay 1983). If ciliates and heterotrophic dinoflagellates typical for the pelagial can similarly respond to the onset of the starvation period by reducing their metabolism, it will greatly prolong their survival.

\section{How long will it take starving, non-feeding ciliates to respire their cell carbon at $-1.5^{\circ} \mathrm{C}$ ?}

This can be estimated using $\mathrm{O}_{2}$ consumption rates for starved ciliate and flagellate species reviewed by Fenchel \& Finlay (1983) and the following assump- tions: cells survive $80 \%$ shrinkage (Caron et al. 1990); carbon content $=0.13 \mathrm{pg} \mathrm{C} \mathrm{m}^{-3}$ and $Q_{10}=2.8$ (Hansen et al. 1997); respiratory quotient $(\mathrm{RQ})=0.8 ; 11 \mathrm{O}_{2}=$ $1.428 \mathrm{~g} \mathrm{O}_{2}$ (the density of $\mathrm{O}_{2}$ gas).

Temperature-corrected cell-specific $\mathrm{O}_{2}$ consumption rates, expressed in $\mathrm{nl} \mathrm{O}_{2}$ cell $^{-1} \mathrm{~h}^{-1}$, from 21 measurements reported in the review were converted to daily respiration rates in carbon units $\left(\mathrm{pg} \mathrm{C} \mathrm{d} \mathrm{d}^{-1}\right)$. For each species, the cell carbon weight, $W$ (pg C), and respiration rate, $r$, were inserted in the allometric equation with an exponent of 0.75 (Fenchel \& Finlay 1983)

$$
r=\mathrm{a} W^{0.75}
$$

The respiration rate was transformed to a specific respiration rate by division with $W$

$$
\frac{r}{W}=a W^{-0.25}
$$

and the constant $a$ isolated. As there was no difference between ciliates and flagellates (Student's $t$-test, $\mathrm{p}>0.05)$ a mean constant $( \pm \mathrm{SD})$ was calculated from all 21 calculations, which gives $a=0.091 \pm 0.056 \mathrm{pg} \mathrm{C}$ $\mathrm{pg}^{-1} \mathrm{C} \mathrm{d}^{-1}$. Inserting $\mathrm{a}$ and the carbon content of a mean sized ciliate of $15000 \mu^{3}$ into Eq. (2) yields an initial weight-specific respiration rate during starvation of $1.4 \% \mathrm{~d}^{-1}(0.5$ to $2.2 \%)$.

The weight loss over time due to respiration can be expressed by the differential equation

$$
\frac{\mathrm{d} W}{\mathrm{~d} t}=-\mathrm{a} W^{0.75}
$$

assuming that the allometric relationship documented at the interspecific level (Eq. 1) is applicable also for a shrinking individual. Inherent in this assumption is that the weight-specific respiration rate of the starving individual increases with time, leading to a conservative estimate of survival time compared to applying a constant specific rate. Eq. (3) can be solved to

$$
W_{t}=\left(-0.25 a t+W_{0}^{0.25}\right)^{4}
$$

where $W_{0}$ is the initial weight and $W_{t}$ is the weight at time $t$. Inserting $W_{t}=0.2 \times W_{0}$ to Eq. (4) and isolating $t$ gives the survival time $t_{20} \%$

$$
t_{20 \%}=\frac{4\left(1-0.2^{0.25}\right) W_{0}^{0.25}}{a}
$$

Using Eq. (5), a calculation for the mean sized, $15000 \mathrm{\mu m}^{3}$, ciliate resulted in a survival period of $3 \mathrm{mo}$ (60 to $252 \mathrm{~d}$ ). The survival periods of the largest $\left(350000 \mu^{3}\right)$ and the smallest $\left(1500 \mu^{3}\right)$ protozoans in Disko Bay with initial specific respiration rates of 0.6 and $2.4 \% \mathrm{~d}^{-1}$, respectively, correspond to 213 and $54 \mathrm{~d}$. Thus, as evident from Eq. (5), survival time relates to the size of the initial cell making it more profitable to 
be large when starvation begins ('survival of the fattest'). The observed size range of Laboea strobila indicates that the selected minimum cell size of $20 \%$ of $W_{0}$ is reasonable. The smallest $L$. strobila cells were $16 \%$ of the largest (Fig. 9). Indeed, reduced metabolic activity may explain survival of at least the largest protozoans even if they were not feeding at all.

The observed loss rate of the protozoans was 4 to $5 \%$ of the community biomass per day (Table 1). It is unknown how much of this loss was due to respiration and how much was due to mortality, and to what degree the cells were still feeding and growing. However, this loss rate is much closer to the loss rates calculated above (assuming reduced metabolism) than to the mortality rates found for starved protozoans in the laboratory, where rates of $>50 \% \mathrm{~d}^{-1}$ are usually reported (e.g. Crawford \& Stoecker 1996).

Based on the discussion of overwintering strategies we suggest that the protozoans survived the winter primarily due to their ability to reduce the maintenance metabolism. We speculate that pelagic protozoans have developed metabolic adaptations to variations in food resources in addition to encystment and hypothesize that there exists a continuum of metabolic stages between exponentially growing cells and cysts. Because of the suggested starvation mode, which was influenced by low temperature, they only needed very rare prey encounters to survive. A simple model of prey encounter in a turbulent environment showed that the protozoans encountered $\sim 3$ prey particles $\mathrm{d}^{-1}$ (calculated according to Kiørboe 1997). Prey encounters of this order of magnitude corresponds to a specific ingestion less than a few percent of the maximum ingestion measured in the laboratory at 12 to $22^{\circ} \mathrm{C}$ (Hansen et al. 1997). Inclusion of ciliates and heterotrophic dinoflagellates in the prey category for the possibility of a heterotrophic population 'feeding on itself' does not change this figure.

On average, the protozoan biomass during the dark months of November to February was $\sim 70 \mathrm{mg} \mathrm{C} \mathrm{m}^{-2}$ (ciliates 40, dinoflagellates 30). Assuming a metabolic rate of $1.4 \% \mathrm{~d}^{-1}$ protozoans would require a primary production of $\sim 1 \mathrm{mg} \mathrm{C} \mathrm{m}^{-2} \mathrm{~d}^{-1}(70 / 100 \times 1.4)$. The average measured production in November to February was about $0.6 \mathrm{mg} \mathrm{C} \mathrm{m} \mathrm{d}^{-2} \mathrm{~d}^{-1}$ (T. G. Nielsen et al. unpubl.). Therefore, despite the fact that primary production is negligible, it (on average) might be large enough to support the populations of protozoa in starvation mode.

We further expect the threshold concentration for growth to show temperature dependency, which would lead to a lowering of reported threshold values. This seems reasonable as respiration is found to scale with temperature for various zooplankton organisms (e.g. Hansen et al. 1997).
Finally, the majority of the ciliates in Disko Bay and an unknown proportion of the dinoflagellates were mixotrophic. They potentially have the additional ability to digest retained plastids during starvation where autophagy occurs, thus having an advantage over strict heterotrophs.

\section{Ice-water interactions and the winter-spring transition}

Prior to the spring phytoplankton blooms ice algae developed in the bottom sea ice. Microscopic evidence suggests that these algae did not contribute significantly to the pelagic community as proposed by Smith \& Nelson (1985) and Michel et al. (1993). Rather, they sedimented quickly out of the euphotic zone and formed a transient food resource for pelagic grazers, when released from the melting ice. This is in accordance with studies, which suggest that ice algae tend to form aggregates with high sinking rates (Carey 1987, Riebesell et al. 1991).

However, before sedimentation and the ice-breakupinduced phytoplankton bloom the ice communities may have provided starved pelagic protozoans with a concentrated food source. The chl a concentration measured at the ice-water interface was several times higher compared to at 2 and $15 \mathrm{~m}$ in the last weeks prior to ice breakup (not shown). Grazing on this algal layer would pre-acclimate the winter populations of protozoa, so that they were not severely starved or even were able to resume growth rapidly after initiation of the phytoplankton bloom. Protozoans need to rebuild their cell machinery before they can resume growth after a starvation period (Fenchel 1982). The short time lag on the spring bloom supports this hypothesis.

The winter populations of ciliates and heterotrophic dinoflagellates acted thus as a 'reservoir' of starvationresistant individuals, which could multiply quickly when favored by the right conditions. Net community growth of protozoans was comparable to that of their phytoplankton prey, and they responded exponentially to the spring phytoplankton bloom almost instantaneously, increasing 100-fold from winter to summer. The exponential net increase occurred despite subzero temperatures and the potential predation impact from a large biomass of Calanus spp. that ascended from their deep-water hibernation in April (Madsen et al. unpubl.).

For shallow-water diatoms, $1 \%$ survival of the cells which sink to the bottom in spring is sufficient to seed the water column the following year (Jewson et al. 1981). A corresponding scenario for Disko Bay protozoans, but assuming a pelagic inoculum, gives a seeding concentration equal to $5 \%$ of the summer concen- 

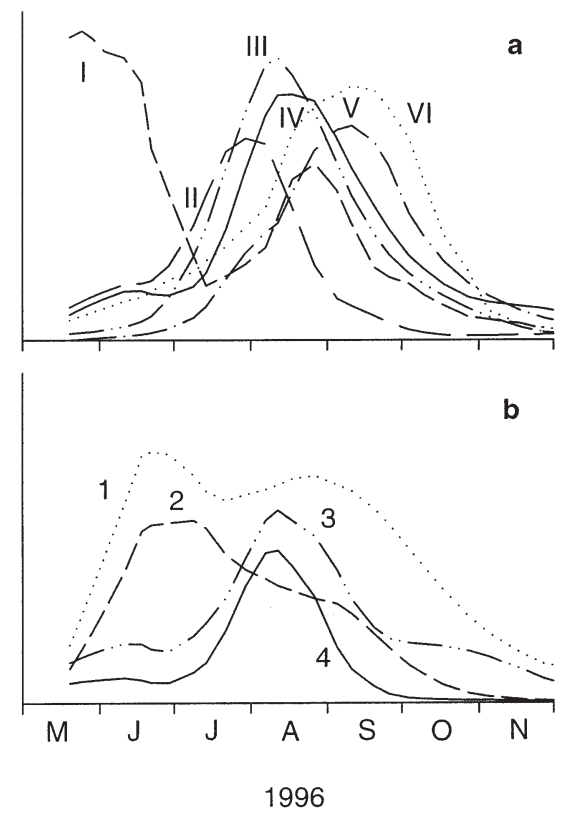

Fig. 11. Succession pattern of selected species of (a) ciliates and (b) heterotrophic dinoflagellates. The biomass values are normalized to the maximum, and curves fitted to data points using Lowess smoothing (SigmaPlot, SPSS Inc.) selecting an $f$ value of 0.2. The species codes are as follows: (I) Lohmaniella oviformis, (II) tintinnids, (III) Strombidium sp., (IV) Strobilidium spiralis, (V) Laboea strobila, (VI) bacterivorous ciliates, (1) Gyrodinium sp., (2) Protoperidinium bipes, (3) thecate dinoflagellates, (4) Gyrodinium spirale

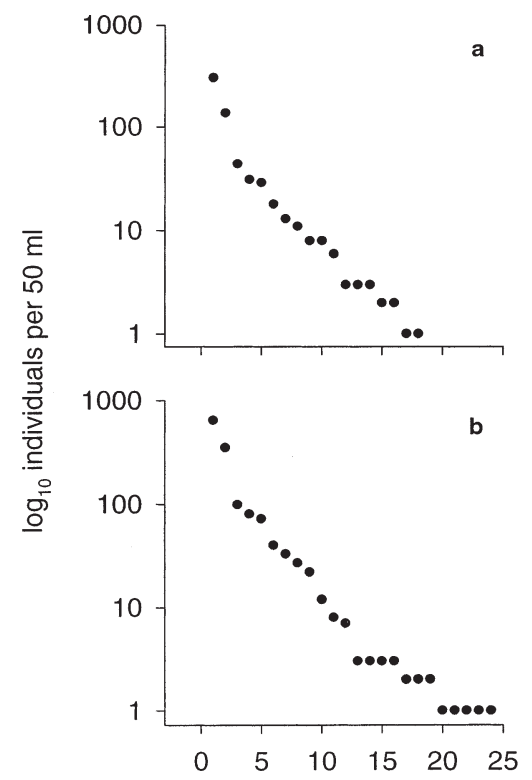

Species ranked according to abundance

Fig. 12. Surface water sample from May 29, 1996, the sample with the most counted individuals during the study, containing (a) 629 dinoflagellates and (b) 1421 ciliates divided among 18 and 24 species, respectively tration (Figs. $3 \& 4$ ). Thus, a winter 'inoculum' of the recorded $262 \pm 181$ cells l$^{-1}$ is sufficient to initiate the succession of protozoa the following year and no other seeding mechanisms are necessary to explain the observed biomass buildup.

\section{Succession and diversity}

Ciliates and heterotrophic dinoflagellates showed a highly diverse succession pattern (Fig. 11). Coexisting species that presumably occupied slightly different niches peaked successively during the summer. The small ciliate Lohmaniella oviformis was one of the earliest species. It increased exponentially from mid-April and reached a peak at around June 1 in both years. In September, it had a second but less pronounced peak. Small bacterivorous ciliates, on the other hand, peaked rather late (October 1) and in between the peaks of these 2 species were peaks of several others. Such seasonal patterns did presumably also exist for the remaining morphospecies that were grouped together in size classes.

At least for ciliates the 'morphospecies' concept appears to be as robust as any other species concept for microbial groups (Finlay 1998). The most striking result of the analysis of diversity is a relatively diverse although dilute winter community. Generally, the morphospecies richness was smaller during winter, but it seems only to be a matter of processing more water to get a higher morphospecies number. In winter, the number of individuals counted was low and $325 \mathrm{ml}$ of water was clearly not enough to find the rare morphospecies. Even when counting 1500 individuals from a single water sample some morphospecies were represented by only 1 to 3 specimens (Fig. 12). Considering that many fewer cells were counted during winter, it is likely that an unknown number of morphospecies was not recorded.

If, for convenience, ciliates and heterotrophic dinoflagellates are divided into 6 functionally and taxonomically different groups (Myrionecta rubra, tintinnids, oligotrichs including the genera Strombidium, Strobilidium, Lohmaniella, Laboea, 'others', gymnodinoid dinoflagellates and peridinoid dinoflagellates), it is noticed that the most abundant protozoan groups and species recorded from this Arctic ecosystem are similar to those reported from the Antarctic Marginal Ice Zone (Edwards et al. 1998) and temperate latitudes (Hansen 1991, Nielsen \& Kiørboe 1994). In addition, the relative importance of these groups seems to be roughly similar. The only exception is thecate dinoflagellates, which seem to be more abundant at temperate latitudes. 


\section{Conclusion}

Compared to in other marine areas, the importance of microbial populations in polar food web dynamics remains poorly documented and does yet not have general acceptance. Ecosystem structure and function in cold waters such as Disko Bay is, however, not different from that at lower latitudes, where protozoan grazers are accepted to play a pivotal role. The present study, through a detailed analysis of the annual pattern of ciliates and heterotrophic dinoflagellates, emphasizes the existence of a microbial community with a high complexity. This complex community of protozoans was maintained even during winter, when the 'obligate' oligotrichous ciliate Laboea strobila and other mixotrophic ciliates were observed. The study stresses that particularly oligotrichous ciliates and athecate heterotrophic dinoflagellates may contribute substantially to the pelagic protozoan biomass in the Arctic. Finally, the winter sampling showed that a small community of ciliates and heterotrophic dinoflagellates could maintain itself in a potentially active state during the dark arctic winter despite living in what seems to be a well-below-food-threshold ecosystem. We suggest that this was accomplished primarily through the ability of the protozoans to reduce their metabolism.

Acknowledgements. We warmly thank the crew on RV 'Porsild' for help during the many cruises. Particularly, we are grateful to Jørgen Broberg and Johannes Filimonsen for their support when the weather and sea were (too) rough. Thanks to the late Leif Skytte for logistical support and to Birgit Søborg for technical assistance. The board of Arctic Station, University of Copenhagen, is acknowledged for letting us use the excellent facilities in Qeqertarsuaq. Thanks to Anja S. Hansen for valuable discussion and insights in mathematics. Finally, we thank Kurt Buck, David W. Crawford, David Montagnes, Diane Stoecker, Helge A. Thomsen, Peter Tiselius, Jefferson T. Turner, Thomas Kiørboe, Peter Verity, Per Juel Hansen and 2 anonymous reviewers for valuable comments on earlier drafts of the manuscript. The investigation was supported by The Danish National Research Council project no. 9501038.

\section{LITERATURE CITED}

Andersen OGN (1981) The annual cycle of temperature, salinity, currents and water masses in Disko Bugt and adjacent waters, West Greenland. Medd Grønl Biosci 5: 1-33

Andersen P (1988) The quantitative importance of the 'microbial loop' in the marine pelagial: a case story from North Bering/Chukchi Seas. Arch Hydrobiol Beih Ergebn Limnol 31:243-251

Bernard C, Rassoulzadegan F (1994) Seasonal variations of mixotrophic ciliates in the northwest Mediterranean Sea. Mar Ecol Prog Ser 108:295-301

Bjørnsen PK, Kuparinen J (1991) Growth and herbivory by heterotrophic dinoflagellates in the Southern Ocean, studied by mesocosm experiments. Mar Biol 109:397-405

Boyd PW, Strom S, Whitney FA, Doherty S, Wen ME, Harrison PJ, Wong CS, Varela DE (1995) The NE subarctic Pacific in winter: I. Biological standing stocks. Mar Ecol Prog Ser 128:11-24

Carey AG Jr (1987) Particle flux beneath fast ice in the shallow Beaufort Sea, Arctic Ocean. Mar Ecol Prog Ser 40: $247-257$

Caron DA, Goldman JC, Fenchel T (1990) Protozoan respiration and metabolism. In: Capriulo GM (ed) Ecology of marine protozoa. Oxford University Press, New York, p 307-322

Conover RJ, Siferd TD (1993) Dark-season survival strategies for coastal zone zooplankton in the Canadian Arctic. Arctic 46:303-311

Crawford DW, Stoecker DK (1996) Carbon content, dark respiration and mortality of the mixotrophic planktonic ciliate Strombidium capitatum. Mar Biol 126:415-422

Dahms HU (1995) Dormancy in the Copepoda - an overview. Hydrobiologia 306:199-211

Edwards ES, Burkill PH, Sleigh MA (1998) Microbial community structure in the marginal ice zone of the Bellinghausen Sea. J Mar Syst 17:87-96

Fauré-Fremiet E (1948) Le rythme de marée du Strombidium oculatum Gruber. Bull Biol Fr-Belg 82:3-23

Fenchel T (1982) Ecology of heterotrophic microflagellates. III. Adaptations to heterogeneous environments. Mar Ecol Prog Ser 9:25-33

Fenchel T (1987) Ecology of protozoa: the biology of free-living phagotrophic protists. Science Tech Publishers, Madison, WI

Fenchel T, Finlay BJ (1983) Respiration rates in heterotrophic, free-living protozoa. Microb Ecol 9:99-122

Fenchel T, Jonsson PR (1988) The functional biology of Strombidium sulcatum, a marine oligotrich ciliate (Ciliophora, Oligotrichina). Mar Ecol Prog Ser 48:1-15

Finlay BJ (1998) The global diversity of protozoa and other small species. Int J Parasitol 28:29-48

Fofonoff NP, Millard RC Jr (1983) Algorithms for computation of fundamental properties of seawater. UNESCO technical papers in marine science 44. Endorsed by UNESCO/ SCOR/ICES/IAPSO Joint Panel on Oceanographic Tables and Standards and SCOR Working Group 51, UNESCO, Paris

Fryxell GA (ed) (1983) Survival strategies of the algae. Cambridge University Press, Cambridge

Garrison DL, Buck KR (1986) Organism losses during ice melting: a serious bias in sea ice community studies. Polar Biol 6:237-239

Garrison DL, Buck KR (1989) Protozooplankton in the Weddell Sea, Antarctica: abundance and distribution in the Ice-Edge Zone. Polar Biol 9:341-351

Garrison DL, Gowing MM (1993) Protozooplankton. In: Friedmann EI (ed) Antarctic microbiology. Wiley-Liss, New York, p 123-165

Garrison DL, Buck KR, Gowing MM (1993) Winter plankton assemblage in the ice edge zone of the Weddell and Scotia Seas: composition, biomass and spatial distributions. Deep-Sea Res I 40:311-338

Grastrup-Hansen D (1998) Succession og fordeling af bakterier og protister under isopbrud i Disko Bugt. MS thesis, Copenhagen University

Haas LW (1982) Improved epifluorescence microscopy for observing planctonic microorganisms. Ann Inst Oceanogr 58:261-266

Hansen PJ (1991) Quantitative importance and trophic role of 
heterotrophic dinoflagellates in a coastal pelagic food web. Mar Ecol Prog Ser 73:253-261

Hansen PJ, Bjørnsen PK, Hansen BW (1997) Zooplankton grazing and growth: scaling within the $2-2000-\mu m$ body size range. Limnol Oceanogr 42:687-704

Hewes CD, Holm-Hansen O, Sakshaug E (1985) Alternate carbon pathways at lower trophic levels in the Antarctic food web. In: Siegfred WR, Condy PR, Laws RM (eds) Proceedings of the 4th SCAR Symposium on Antarctic biology. Springer-Verlag, New York, p 227-283

Hirche HJ (1996) Diapause in the marine copepod, Calanus finmarchicus - a review. Ophelia 44:129-143

Jacobsen HH, Hansen PJ (1997) Prey size selection, grazing and growth response of the small heterotrophic dinoflagellate Gymnodinium sp. and the ciliate Balanion comatum - a comparative study. Mar Ecol Prog Ser 158:75-86

Jespersen AM, Christoffersen K (1987) Measurements of chlorophyll a from phytoplankton using ethanol as extraction solvent. Arch Hydrobiol 109:445-454

Jewson DH, Rippey BH, Gilmore WK (1981) Loss rates from sedimentation, parasitism, and grazing during the growth, nutrient limitation, and dormancy of a diatom crop. Limnol Oceanogr 26:1045-1056

Jochem FJ (1999) Dark survival strategies in marine phytoplankton assessed by cytometric measurement of metabolic activity with fluorescein diacetate. Mar Biol 135: 721-728

Jonsson PR (1986) Particle size selection, feeding rates and growth dynamics of marine planktonic oligotrichous ciliates (Ciliophora: Oligotricina). Mar Ecol Prog Ser 33:265-277

Kim YO, Taniguchi A (1995) Excystment of the oligotrich ciliate Strombidium conicum. Aquat Microb Ecol 9:149-156

Kiørboe T (1997) Small-scale turbulence, marine snow formation, and planktivorous feeding. Sci Mar 61(Suppl 1): 141-158

Kivi K, Setälä O (1995) Simultaneous measurement of food particle selection and clearence rates of planktonic oligotrich ciliates (Ciliophora: Oligotrichina). Mar Ecol Prog Ser 119:125-137

Leakey RJG, Fenton N, Clarke A (1994) The annual cycle of planktonic ciliates in nearshore waters at Signy Island, Antarctica. J Plankton Res 16:841-856

Levinsen H, Nielsen TG, Hansen BW (1999) Plankton community structure and carbon cycling on the western coast of Greenland during the stratified summer situation. II. Heterotrophic dinoflagellates and ciliates. Aquat Microb Ecol 16:217-232

Lynn DH, Corliss JO (1991) Ciliophora. In: Harrsison FW (ed) Microscopic anatomy of invertebrates, Vol 1, Protozoa. Wiley-Liss, New York, p 333-467

Margalef R (1951) Diversidad de especies en las comunidades naturales. Publ Inst Biol Apl Barcelona 9:5-27 (in Spanish with English summary)

Michel C, Legendre L, Therriault JC, Demers S, Vandevelde $\mathrm{T}$ (1993) Springtime coupling between ice algae and phytoplankton assemblages in southeastern Hudson Bay, Canadian Arctic. Polar Biol 13:441-449

Montagnes DJS (1996) Growth responses of planktonic ciliates in the genera Strobilidium and Strombidium. Mar Ecol Prog Ser 130:241-254

Nielsen GÆ, Bresta AM (1984) Guidelines for measurements of phytoplankton primary production. Baltic Mar Biol Publ $1: 1-23$

Nielsen TG, Hansen BW (1995) Plankton community structure and carbon cycling on the western coast of Greenland during and after the sedimentation of a diatom bloom. Mar Ecol Prog Ser 125:239-257
Nielsen TG, Kiørboe T (1994) Regulation of zooplankton biomass and production in a temperate, coastal ecosystem. 2 . Ciliates. Limnol Oceanogr 39:508-519

Nielsen TG, Kiørboe T, Bjørnsen PK (1990) Effects of a Chrysochromulina polylepis subsurface bloom on the planktonic community. Mar Ecol Prog Ser 62:21-35

Paranjape MA (1987) Grazing by microzooplankton in the eastern Canadian Arctic in summer 1983. Mar Ecol Prog Ser 40:239-246

Paranjape MA (1988) Microzooplankton in Lancaster Sound (eastern Canadian Arctic) in summer: biomass and distribution. Deep-Sea Res 35:1547-1563

Pierce RW, Turner JT (1992) Ecology of planktonic ciliates in marine food webs. Rev Aquat Sci 6:139-181

Putt M (1990) Abundance, chlorophyll content and photosynthetic rates of ciliates in the Nordic Seas during summer. Deep-Sea Res 37:1713-1731

Reid PC (1987) Mass encystment of a planktonic oligotrich ciliate. Mar Biol 95:221-230

Riebesell U, Schloss I, Smetacek V (1991) Aggregation of ice algae released from melting sea ice: implication for seeding and sedimentation. Polar Biol 111:239-248

Rivkin RB, Anderson MR, Lajzerowicz C (1996) Microbial processes in cold oceans. I. Relationship between temperature and bacterial growth rate. Mar Ecol Prog Ser 10: 243-254

Rysgaard S, Nielsen TG, Hansen BW (1999) Seasonal variation in nutrients, pelagic primary production and grazing in a high-Arctic coastal marine ecosystem, Young Sound, Northeast Greenland. Mar Ecol Prog Ser 179:13-25

Scharek R, Smetacek V, Fahrbach E, Gordon LI, Rohardt G, Moore $S$ (1994) The transition from winter to early spring in the eastern Weddell Sea, Antarctica: plankton biomass and composition in relation to hydrography and nutrients. Deep-Sea Res I 41:1231-1250

Sherr EB, Sherr BF, Fessenden L (1997) Heterotrophic protists in the Central Arctic Ocean. Deep-Sea Res II 44: $1665-1682$

Smetacek V (1981) The annual cycle of protozooplankton in the Kiel Bight. Mar Biol 63:1-11

Smetacek V, Scharek R, Nöthig EM (1990) Seasonal and regional variations in the pelagial and its relationship to the life history cycle of krill. In: Kerry KR, Hempel G (eds) Antarctic ecosystems, ecological change and conservation. Springer-Verlag, Berlin, p 103-114

Smith WO Jr, Nelson DM (1985) Phytoplankton bloom produced by a receeding ice edge in the Ross Sea: spatial coherence with the density field. Science 227:163-166

Sonneman JA, Hill DRA (1997) A taxonomic survey of cystproducing dinoflagellates from recent sediments of Victorian coastal waters, Australia. Bot Mar 40:149-177

Stoecker DK, Silver MW (1990) Replacement and aging of chloroplasts in Strombidium capitatum (Ciliophora: Oligotrichida). Mar Biol 107:491-502

Stoecker DK, Davis LH, Provan A (1983) Growth of Favella sp. (Ciliata: Tintinnina) and other microzooplankters in cages incubated in situ and comparison to growth in vitro. Mar Biol 75:293-302

Stoecker DK, Silver MW, Michaels AE, Davis LH (1988) Obligate mixotrophy in Laboea strobila, a ciliate which retains chloroplasts. Mar Biol 99:415-423

Stoecker DK, Taniguchi A, Michaels AE (1989) Abundance of autotrophic, mixotrophic and heterotrophic planktonic ciliates in shelf and slope waters. Mar Ecol Prog Ser 50: 241-254

Strickland JDH, Parsons TR (1972) A practical handbook of seawater analysis. Bull Fish Res Board Can 167 
Verity PG, Stoecker DK, Sieracki ME, Nelson, JR (1996) Microzooplankton grazing of primary production at $140^{\circ} \mathrm{W}$ in the equatorial Pacific. Deep-Sea Res II 43: 1227-1255

von Bröckel K (1981) The importance of nanoplankton within

Editorial responsibility: Otto Kinne (Editor),

Oldendorf/Luhe, Germany the pelagic Antarctic ecosystem. Kieler Meeresforsch Sonderh 5:61-67

Wickham SA, Gilbert JJ, Berninger UG (1993) Effects of rotifers and ciliates on the growth and survival of Daphnia. J Plankton Res 15:317-334

Submitted: September 20, 1999; Accepted: May 4, 2000

Proofs received from author(s): September 25, 2000 